\title{
Performance evaluation of diesel and electric operated tube wells irrigation system in sub-tropical conditions
}

\author{
Zia Ullah $^{1 *}$, Ruh Ullah ${ }^{2}$, Murad Ali $^{3}$ and Muhammad Junaid ${ }^{1}$ \\ 1. Department of Water Management, The University of Agriculture Peshawar, Pakistan \\ 2. Department of chemical engineering, Qatar University, Qatar \\ 3. Department of Soil and Environmental sciences, The University of Agriculture Peshawar, Pakistan \\ *Corresponding author's email: nziakhan23@gmail.com
}

Citation

Zia Ullah, Ruh Ullah, Murad Ali and Muhammad Junaid. Performance evaluation of diesel and electric operated tube-wells irrigation system in sub-tropical conditions. Pure and Applied Biology. Vol. 5, Issue 1, 2016 , pp142-148. http://dx.doi.org/10.19045/bspab.2016.50019

\begin{tabular}{llll}
\hline \hline Received: 21/10/2015 & Revised: 12/01/2016 & Accepted: 18/01/2016 & Online First: 01/02/2016 \\
\hline \hline
\end{tabular}

\section{Abstract}

The research study was conducted in district Buner on performance evaluation of diesel and electric operated tube wells irrigation system. The objectives of the study were to find the discharge of tube wells, power consumption, cropping pattern, tenancy status, type of tube wells and well depth. Data was collected using simple questionnaire and discharges were measured by volumetric method. Results showed that $73 \%$ of the farmers were owner in the study area. The maize $(90 \%)$ and wheat $(60 \%)$ were the dominant crops followed by Tobacco $(36 \%)$ grown as a cash crop. A declining trend was observed in tube well construction with the passage of time. Diesel operated tube wells were $93 \%$ and electric operated were $7 \%$ while the same percentage was recorded in private and public tube wells respectively. It was recommended that High power engines should be installed to increase the discharge of tube wells, tube well construction should be encouraged to fulfill irrigation requirements, Diesel and electric operated tube wells should be replaced by solar panel operated turbines.

Key words: Tube well; Power consumption; Well depth; Discharge; Cropping pattern

\section{Introduction}

Today's world population of 6000 million is expected to reach about 8100 million by 2030, an increase of $35 \%$ [1]. The development of agriculture in Pakistan has suffered greatly from the shortage of irrigation water. About 50\% of the cultivable land in Pakistan is still without irrigation [2]. The number of tubewells has increased from less than 30 thousand in 1965 to more than one million in 2010 [3]. Resultantly, groundwater abstractions through these tube wells have gone up to 60 $\mathrm{km}^{3}$ each year, which exceed the annual recharge of $55 \mathrm{~km}^{3}$ [4]. The gap between replenishment and extractions is lowering the water tables significantly with more than 3 meters annually in some areas [5]. Declining water tables are making groundwater supplies economically unviable for irrigation in many regions [6], and are creating environmental problems [7]; [8]; [9]. In the Khyber Pakhtunkhwa of Pakistan total cropped area during 2002-2004 was over 1.92 million hectares of the total cropped area 0.96 million hectares (i.e. 
$50 \%$ ) was irrigated, of the total irrigated area in the province over $80 \%$ was canal irrigated whereas tubewell irrigation amounted to $12 \%$. The rest of the irrigation was covered by artesian well, tank and other [10].

\section{Problem statement}

According to geological survey of Pakistan, tube well irrigation is more suitable than canals (because the cultivated land is spread all over the country in small pockets separated by rivers and mountains etc) where canal irrigation is either not possible or uneconomical. Hence, the proposed study was conducted in order to study the performance evaluation of diesel and electric operated tube well irrigation system in district Buner, to find the discharge of tube wells and to relate it with power consumption, cropping pattern, tenancy status, type of tube wells, date of constructions, category wise distribution of tube wells and well depth.

\section{Materials and methods}

\section{Climate of the study area}

The study was conducted in District Buner of the Khyber Pakhtunkhwa (KP). The overall climate of Buner can be termed as dry sub-tropical with mostly pleasant weather throughout the year. Winter last for 4 to 5 months with mild harshness and the summers are mildly torrid. There are two main rainy seasons; the winter rains in the Rabi season which occurs in November and May. The summer monsoon in the Kharif season provides necessary water for respective crops. Tobacco and wheat are Rabi crops while sugarcane and Maize are the main Kharif crops. Because of the absence of river and canal system a considerable number of tubewells (both electric and diesel) are operated in the area. The district is rich in groundwater.

\section{Data collection}

The study was based on primary data collected in June-August 2013 and the questionnaire was used as a research tool for collection of data required for the study. A total of ten (10) villages, namely Kowga, Nawagai, Sura, Agarai, Anghapore, Karapa, Chena, Koreya, Kankoyai, and Daggar were selected for the study.

\section{Questionnaire}

A simple questionnaire was prepared for data collection according to the objectives of the study. The questionnaire was pretested and after modification it was adopted for data collection. A total of thirty respondents were interviewed. They were interviewed in their native language in order to get accurate information. Farmers were interviewed regarding their tenancy status, cropping pattern, type of tube wells, date of constructions, category wise distribution of tube wells and well depth and the power and discharge relation was evaluated.

\section{Tube well discharge}

Discharge of 30 tube wells were measured in selected villages of district Buner. Volumetric technique was used for measurement of tube well discharges. The discharge of a tube wells were determined from basin. The volume of the Basin was determined and the time taken by filling was recorded. Tube well discharge can be calculated by the following formula.

$\mathrm{Q}=\mathrm{V} / \mathrm{t}(\mathrm{m} 3 / \mathrm{s})$

Where

$\mathrm{V}=$ Volume of stilling basin;

Length $(\mathrm{m}) \mathrm{x}$ Width $(\mathrm{m}) \mathrm{x}$ Height $(\mathrm{m})$

$\mathrm{W}=$ Width of stilling basin $(\mathrm{m})$

$\mathrm{H}=$ Height of the stilling basin $(\mathrm{m})$

$\mathrm{L}=$ Length $(\mathrm{m})$

$\mathrm{Q}=$ Discharge $\left(\mathrm{m}^{3} / \mathrm{s}\right)$

$\mathrm{T}=$ Seconds

\section{Power and discharge relation}

The power and discharge of selected tube wells were plotted on the graph, power $(\mathrm{H})$ on $\mathrm{X}$-axis while discharge $(\mathrm{Q})$ on $\mathrm{Y}$-axis in order to find out the relationship. The power of the engine was found from the initial record of the tube well from the farmers. 
The horse power was converted in to kilowatt by the following formula.

\section{Kilowatt $=H P * 0.76$}

Hp: horsepower,

0.76: conversion constant

\section{Results and discussion}

\section{Tenure status}

There were no legal rules and rights found for tenancy in the study area. The relationship between the farmers and land lords vary from place to place and depend on the understanding between them. Figure 1 shows that $73 \%$ of the farmers were owner, $4 \%$ were tenant, and $23 \%$ were owner cum tenant. Most of the lands were the property of the farmers who live near their land. The only tenancy were unprofitable because some time the catastrophe destroy the crops and the famers have to compensate that in the next season and will pay to the land lord. This is why a very low percentage of the tenants were found. The owner cum tenants has an advantage over the tenants by compensating from his own lands. The people of the study area depend on the ground water as the only source of irrigation due to the absence of surface irrigation system.

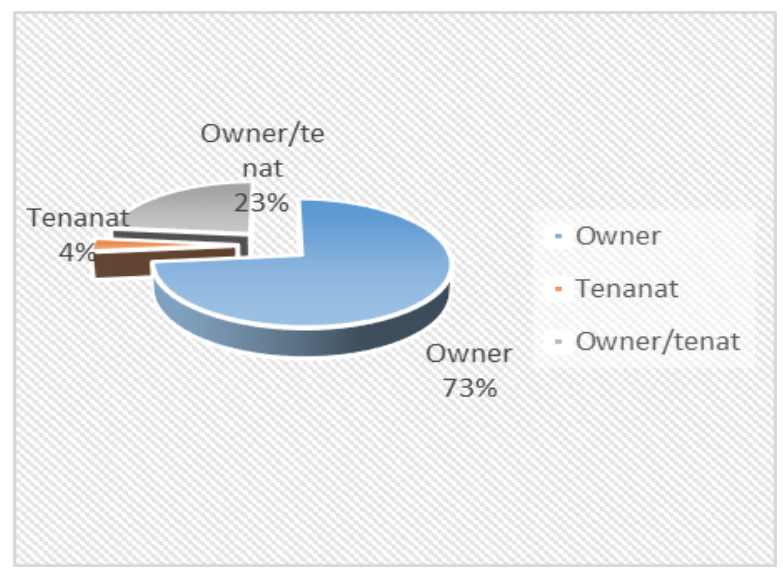

Figure 1. Tenure status of the farmers in the study area

\section{Cropping pattern}

The cropping pattern of the study area for Kharif and Rabi seasons are shown in Figure
2 and 3. It is clear from Figure 2 that dominant crop grown was maize $(90 \%)$ in Kharif season, followed by Okra grown on an area of $(6 \%)$, tomato $(2 \%)$ and other vegetables (2\%). In Rabi season, the dominant crop grown was wheat (60\%), followed by tobacco (36\%) and vegetable $(2 \%)$. The sugarcane was also grown on area of $(1 \%)$. It was also observed that one percent $(1 \%)$ of the total area was fallow in Rabi season. In Rabi season wheat was extensively grown $(60 \%)$ in the study area because it is a staple diet of the area and farmers also earn a handsome amount for wheat straw. In Kharif season dominant crop was maize which was extensively grown by the farmers $(90 \%)$ in the study area, the reason is that the farmer stresses to grow their own cereals to meet their family needs and to have fodder for their animals. They grew various vegetables on small area for sale in the open market to earn income. Tobacco is the second large dominant cash crop of the study area. According to the Bureau of statistics KPK 2006-2007 8\% of the total provincial tobacco's production comes from District Buner. The main problem is the uncertain water provisions, as comparatively the whole of the area is dependent on rain water for irrigation. Due to Agro-climatic and soil fertility Tobacco is the most profitable cash crop of the study area.

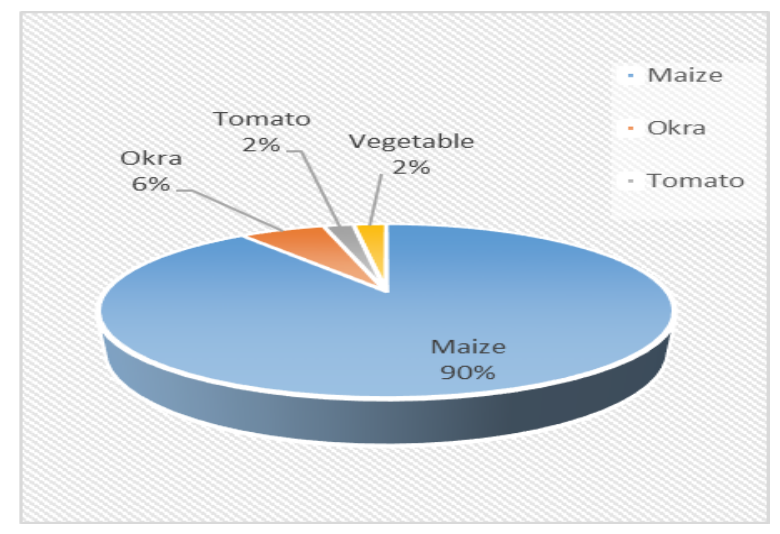

Figure 2. Cropping pattern in Kharif season under tube well irrigated command area 


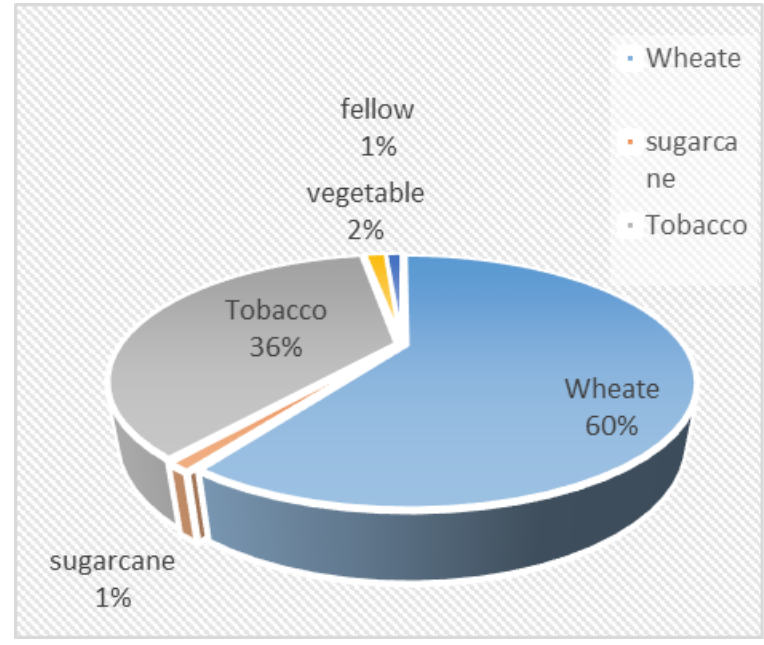

Figure 3. Cropping pattern of Rabi season in tube well irrigated area

\section{Type of tube wells}

Considerable amount of diesel operated tube wells were observed while electric motor driven pumps decreased in number. Figure 4 shows that $93 \%$ of tube wells were diesel operated and $7 \%$ were electric operated. Reasons for preferences of diesel engine operated tube wells over electric driven pumps include low installation costs, continuous supply (no power cuts off), suitability for disjointed lands, and no supplies of any reserved money [11]. Although operational costs of electric motor driven tube wells are less than that of diesel tube wells but, yet, they are low in number due to high installation cost, difficult and time overwhelming procedures to get the approval and installation of electric supply in the study area. There is a huge break between supply and demand which is managed by power supply cuts for long hours. Due to the power crises especially in summer season, when a huge amount of water is needed for the cops, tube wells are closed. Most of the farmers were owner cultivators and were for away from the settled areas, where they had no approach to the electric power.

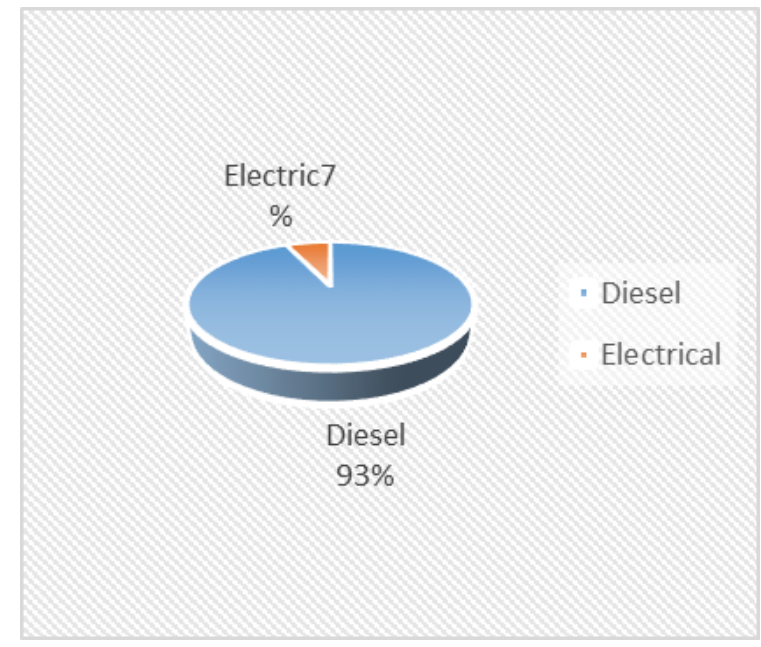

Figure 4. Types of power sources used for operating of tube wells

\section{Date of construction}

Figure 5 shows the date of tube wells construction. Figure shows that a rapid growth was observed from 1990 to 2005, after that the declining trend was observed. Reason for rapid growth and then declining was that, in the beginning the tube well showed a tremendous output which facilitates the farmers to construct the tube wells. With the passage of time when large amount of tube wells constructed water table got down so slowly and gradually the need of deep tube wells were felt in the study area. It was difficult for small land holders to afford high construction costs, this is why a declining trend was observed.

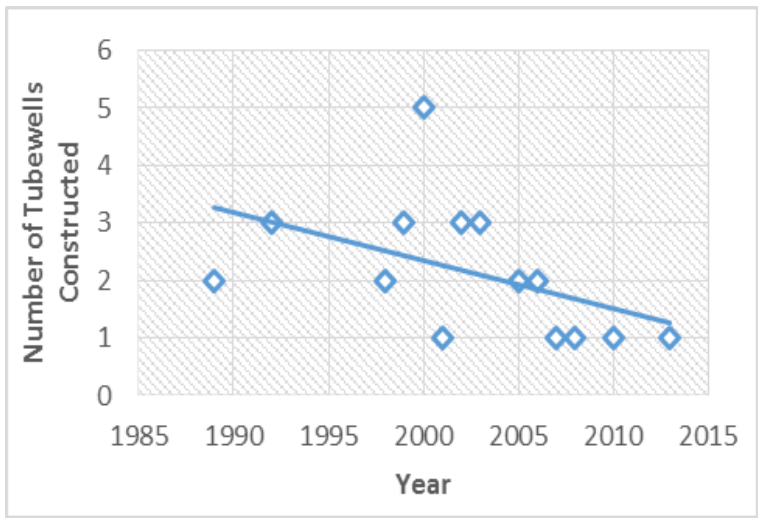

Figure 5. No. of tube wells with year of construction 


\section{Category wise distribution of tube wells}

Figure 6 shows that $93 \%$ of the tube wells were private while $7 \%$ were government in the study area. The farmers were on the view that private tube wells are most efficient than government, because many farmers share same tube well on the basis of warabandi system, and there is no surety that one may get the exact amount of water on time. Supporting the arguments about private tube wells many farmers reported that, warabandi rules were made by the irrigation department but farmers did not follow that rules and made their own schedule, based on first come first reserve. The influential people of the area have benefits of this principle because they had no limit of time and the small farmers were suffered a lot. The installations of private tubewells were encouraged by the influential farmers who used to get unlimited amount of water.

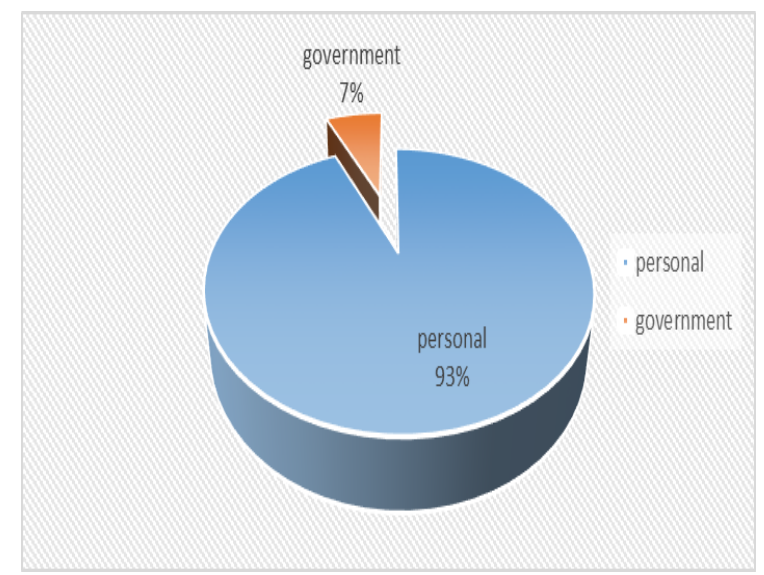

Figure 6. Category wise distribution of tube wells

\section{Well depth}

On the basis of well depth the tube wells in the study area have been divided in to two categories, Shallow and deep tube wells. Shallow wells were considered from $0-100$ $\mathrm{ft}$, while the deep wells were above $100 \mathrm{ft}$. Figure 7 shows that only $2.4 \%$ of the total wells were shallow while figure 8 shows deep wells. The reason is that, when it is compared with the figure 5 , it shows that, in the beginning of tube wells construction the water table was less than $100 \mathrm{ft}$, while as the number of tube wells increased the water table moved downward, consequently the need of deep tube wells were felt. The deeper a wells, the higher its cost of construction and per unit volume of water abstraction, irrespective of the device used for lifting water. Though the shallow wells have little cost of construction and low cost per volume of water abstraction but the people do not prefer to construct shallow wells because it yields such a little water that cannot fulfill the requirements.

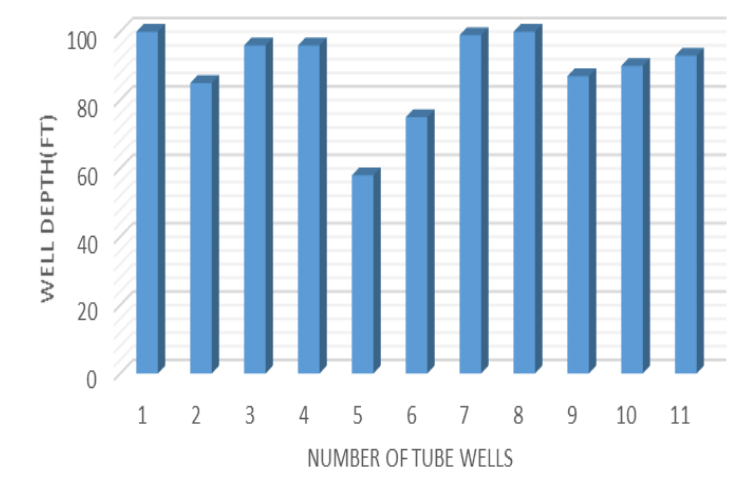

Figure 7. Well depth in the study area (Shallow)

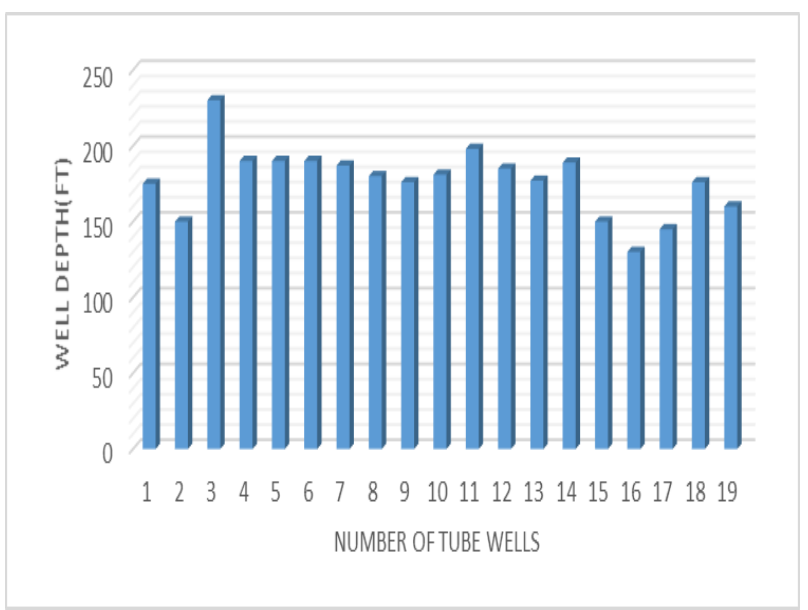

Figure 8. Wells depth in the study area (Deep) 


\section{Flow discharge of tube wells}

Figure 9 shows discharge of tube wells in the study Area. The minimum discharge was 8.5 liter $\mathrm{sec}^{-1}$ which were calculated from shallow tube wells while the maximum discharge was 19 liter $\mathrm{sec}^{-1}$ for deep tube wells, average discharge was 12.9 liter sec ${ }^{-1}$. Discharge of tube wells less than 10 liter $\mathrm{sec}^{-1}$ were considered low discharge, because the engine power of that tube wells were low than the one installed on deep tube wells. Deep tube wells have the capacity to provide enough water to fulfill the pumping need of high power engines, while shallow tube wells provide less water which is enough for the small land holders up to some extent.

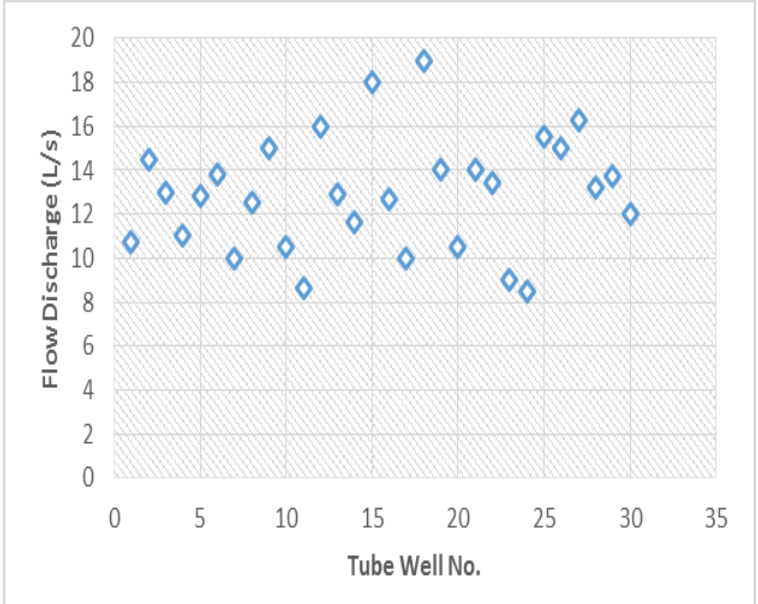

Figure 9. Flow discharge of Tube wells

\section{Power and flow discharge relationship}

Figure 10 shows that as the engine power increases discharge increases and vice versa. The minimum discharge of 8.6 liter $\mathrm{sec}^{-1}$ was recorded at a tube wells having power $12 \mathrm{hp} \mathrm{(9.12watt)} \mathrm{while} \mathrm{the} \mathrm{maximum}$ discharge was 19 liter $\mathrm{sec}^{-1}$ with a tube wells having power $50 \mathrm{hp}$ (38watt). Figure also shows that two tube wells of high discharge 18 and 19 liter $\mathrm{sec}^{-1}$ respectively was recorded had a high power engines $50 \mathrm{hp}$ (38watt), which was constructed by the government to cover a large area.

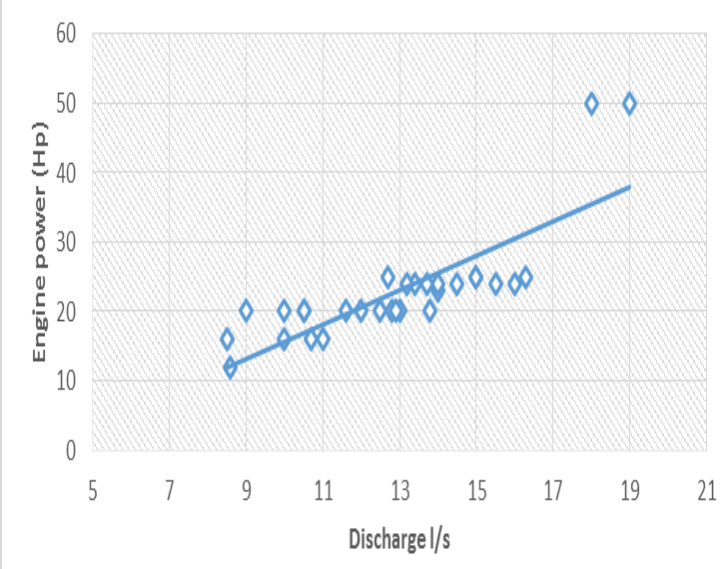

Figure 10. Tube well flow discharge and engine power

\section{Conclusions and recommendation}

It is concluded from the above results that most of the farmers in the study area were owner cultivators. The major cash crop was tobacco grown with a proportion of $36 \%$. Maize was the dominant crop during Kharif season with a proportion of $90 \%$ while the wheat was dominant in winter season with a proportion of $60 \%$. It was observed that tube wells constructions trend was decline with a passage of time. The maximum discharge was 19 liter $\mathrm{sec}^{-1}$ which increase with the increase of engine power.

When the economic conditions of the people in the study area are in consideration, it is recommended that the government should give subsidy to the farmers to construct deep wells with a high power engines to increase the flow discharge. Besides, the electric and diesel engines should be replaced by solar panel operated turbines.

Authors' contributions

Conceived and designed the experiments: R Ullah, Performed statistical analysis: M Ali \& M Junaid, Analyzed the data: Z Ullah, Wrote the paper: Z Ullah. 


\section{References}

1. Playan E \& Mateos L (2006). Modernization and optimization of irrigation systems to increase water productivity. Agric Water Manage 80: 100-6.

2. MINFAL (2007). Agricultural Statistics of NWFP. Ministry of Food Agriculture and Livestock Peshawar.

3. Chaudhry MJ (1990). The adoption of tubewell technology in Pakistan. The Pak Dev Review 29 (3\&4): 291-303.

4. FAO (2009). AQUASTAT (http://www.fao.org/nr/water/aquastat/ma in/index.stm; accessed 19 August 2012.

5. Ahmad S (2007). Building high performance knowledge institution for water resources in Baluchistan Water for Balochistan Policy Briefings 3(4), Project for "Supporting Implementation of IWRM Policy in BalochistanGovernment of Balochistan-ADB and Royal Government of Netherlands.

6. Banerji A, Meenakshi JV \& Khanna G (2006). Groundwater irrigation in North India: institutions and markets. South Asian Network for Development and Environmental Economics, P.O. Box 8975, EPC 1056 Kathmandu, Nepal.

7. Shah T, Molden D, Sakthivadivel R \& Seckler D (2000). The global groundwater situation: overview of opportunities and challenges. Colombo, Sri Lanka: International Water Management Institute.

8. Khan AH, Peter M \& Asim RK (2008). Evolution of managing water for agriculture in the Indus River Basin. International Water Management Institute (IWMI) Lahore, Pakistan. Playan, E. and L. Mateos. Modernization and optimization of irrigation systems to increase water productivity. Agric. Water Manag. 80: 100-6.

9. Qureshi AS, McCornick PG, Sarwar A \& Sherma BR (2009). Challenges and prospects of sustainable groundwater management in the Indus Basin, Pakistan. Water Resources Management 24: 15511569.

10. Aurangzeb M (2007). Irrigation cost of major crops: A comparison of electric and diesel tubewells irrigation in district Charsadda (NWFP-Pakistan). Sarhad J of Agri 23(1): 217.

11. Qureshi AS, Shah T \& Akhtar M (2003). The groundwater economy of Pakistan. Working Paper 64. Lahore, Pakistan: International Water Management Institute. 